\title{
Resource Potential for Sustainable Development of Agricultural Enterprises
}

\author{
Sokolova E.V.* \\ Department of Humanitarian, Social-Economic and \\ Fundamental Disciplines \\ Tara Branch of Omsk SAU \\ Tara, Russia \\ e-mail: ev.sokolova@omgau.org
}

\author{
Zakharova T.I. \\ Department of Humanitarian, Social-Economic and \\ Fundamental Disciplines \\ Tara Branch of Omsk SAU \\ Tara, Russia
}

\begin{abstract}
The paper is devoted to comprehensive study of the resource potential of agricultural enterprises as one of the factors for sustainable development of the region. Systemic changes in modern society require new approaches to understanding the concept of 'resource potential'. Informatization of society and digitalization of agriculture imply new attitudes and views on the use of resource support for agricultural enterprises. Based on the analysis of approaches to the concept of 'resource potential' available in domestic and foreign science, the authors understand the potential of an agricultural enterprise as a set of material, energy, information and labor resources. The study aims to investigate the structure of the resource potential of agricultural enterprises in postindustrial society and to identify factors that ensure the effectiveness of its use. The methodological basis of the study was the principle of interdisciplinarity and consistency, which allowed us to treat the phenomena studied from different angles, as a whole that consists of interrelated components. The authors consider the resource potential of the region to be a synthetic indicator: each individual resource does not evaluate the enterprise activities. The authors highlight that competent management of the available resources by the enterprise is the key to its successful functioning, and its personnel is the core of the resource potential of any enterprise.
\end{abstract}

Keywords - resource potential; human capital; sustainable development; systemic changes.

\section{INTRODUCTION}

The agricultural sector is one of the most important sectors of the Russian economy, and systemic changes of modern society have significantly affected agricultural enterprises. These changes are bilateral in nature. On the one hand, technical re-equipment of enterprises and digitalization of agriculture enhance the development of the industry, and, on the other hand, they require the revision, activation and use of resources of the industry. This determines the relevance and practical significance of the study. The purpose of the study is to investigate the structure of the resource potential of agricultural enterprises in post-industrial society and to identify factors that ensure the effectiveness of its use.

\section{METHODOLOGY AND Literature REVIEW}

The concept of 'resource potential' is widely considered in economic science. Today, there are several approaches to its understanding. E.V. Bogomolova and T.N. Tolstykh [1] define the resource potential as the totality of all types of interrelated resources of the entrepreneurial structure, which are used to achieve the maximum economic effect. B.I. Smagin refers the resource potential to the combination of labor, natural and material costs, determined by quantity, quality and internal structure of each resource [2]. V.A. Svobodin encompasses in the concept of 'resource potential' the totality of all resources of the enterprise [3]. A.P. Shatrova focuses on the potential of the enterprise and considers it necessary to draw all unused resources, which are currently available or will be available in the external environment, into employment [4].

The authors understand the concept of 'resource potential' as a set of material, energy, information and labor resources of the agricultural enterprise. The essence of the studied concept allows us to talk about the resource potential of the enterprise as one of the driving factors for its development. It should be noted that not only material but also intangible assets determine the capabilities of the agricultural enterprises and have a significant impact on its effective functioning. The intangible assets include the level of development of the social sphere and personnel of enterprises - producers of agricultural products.

The methodological basis of the study is the key approaches and principles of modern science: a systematic approach and the principle of interdisciplinarity. The systematic approach made it possible to consider the phenomena under study through various lenses, as a whole that consists of interrelated components.

Interdisciplinarity made it possible to use the achievements of modern social sciences, which is necessary for such studies.

\section{RESULTS}

Sustainable development of agricultural enterprises depends on many factors, and resource potential is only one of them. However, competent use of the resources available to the enterprise is the key to its successful functioning.

A distinctive feature of the resource potential of agricultural enterprises is its close dependence on climatic and environmental conditions of a particular territory. They determine the specifics of agricultural production: crop growing and animal breeding. This is how the vector of development of agricultural enterprises is determined. A clear management system based on the advances of science and best 
practices helps consider natural phenomena and minimize their impact on the production process $[5,6]$. Centers for collective use of research equipment have been created at Omsk State University to provide close interrelation between science and production, thereby enriching the resource potential of enterprises in the agricultural sector. The center for collective use of research equipment 'Agrarian and technological research' is the most promising in the field of research and analysis of the resource potential for sustainable development of agricultural enterprises.

The main factors of agricultural production are another major component of the resource potential of agricultural enterprises. Namely, the quantity and quality of agricultural land (land as a factor of production), the quality and condition of the material and technical base (capital as a factor of production), and qualified labor resources involved in the industry (labor as a factor of production).

However, favorable climatic conditions and land availability for agricultural purposes do not guarantee the enterprise effectiveness. In this regard, an important component of the resource potential is a competent managerial apparatus, which will combine all the resources of the enterprise into a single system, and not use them separately. This will create the conditions for predicting the further effective activity of the enterprise, increasing and enriching its resource potential.

We consider the personnel to be the core of the resource potential of any enterprise. The issues related to the study of human capital are addressed by both domestic and foreign researchers [7-15]. Formation of the personnel potential of agricultural enterprises today is fraught with a number of difficulties. Firstly, the declined popularity of agricultural labor entails the lack of desire to work in agribusiness among young people. This problem is one of the urgent and requires a solution. This process runs in parallel with the special need of agricultural enterprises for qualified personnel. Digitalization of agriculture requires specialists of a different level with not only subject specific knowledge but also with a wide range of skills.

One of the main subjective factors in formation of human capital is a high level of consciousness displayed when investing resources in education, advanced training, health, and raising the level of culture. Special attention should be paid to formation of sustainable positive motivation. Formation of motivation is a complex and lengthy process that involves all social institutions of society. It is motivation that often underlies self-improvement, both personal and professional, determines a person's attitude to work and results in a quality product. The efforts of not only the state, but also society as a whole and the immediate environment of a person should be joined to form a sustainable positive motivation.

Another component of the resource potential of the enterprise is its technical equipment. In the context of comprehensive modernization of the agricultural sector, technical re-equipment of enterprises requires significant financial investments. However, internal funds of agricultural producers are often insufficient. Most enterprises are limited in opportunities for attracting external long-term investments. High cost and long payback period complicates acquisition of new technology. The situation is particularly difficult in small enterprises. The degree of wear and tear of the equipment is high; it requires large investments in repairs. As a result, its productivity and efficiency is low.

The enterprise technical potential is assessed with regard to technological, economic and environmental characteristics of machinery and equipment. Technical characteristics of the machines and the availability of specialists capable of operating these machines are also considered.

The technological component of the resource potential also plays a significant role in the development of the enterprise. This component is especially relevant in the context of the transition from fuel-and-resource-based economy to an innovative technological one. This trend requires creation of a holistic innovation system with a developed technology market, developed infrastructure and legal intellectual property protection. Ensuring food security of the state makes technologization of high priority for agricultural enterprises.

It should be noted that the concept of 'resource potential' is a synthetic indicator. In other words, individual qualitative and quantitative calculations of the enterprise efficiency are not informative and cannot be used for elaboration of the long term development plan. All the components of the resource potential in their relationship should be considered to calculate all the revenues and risks in the short and long term. Moreover, this approach is applicable both to the agricultural sector of the region and to a single enterprise.

In recent decades, the structure of the resource potential of agricultural enterprises has become much more complicated. To date, the resource potential includes such components as innovative, informational and investment potential. These resources not only attract new capital but also make the company attractive to young professionals. We believe that an increase in the resource potential does not depend on its volumes, but it strongly depends on a competent, deep and systematic structural and component analysis of resources

Another important aspect of this concept is the interrelation of all components of the resource potential. This is especially true for agricultural enterprises, as a number of dependencies can be clearly observed. For example, the dependence of the agricultural specialization of the region or enterprise on climate and environmental conditions or the dependence of the production level on implementation of advanced developments of agricultural science. In this regard, complexity and consistency are the key characteristics of the resource potential.

Management mechanisms are of great importance for the enterprise to function effectively, and for its resources to be maximally involved into circulation. According to some researchers, the mechanism for managing the resource potential of agricultural enterprises should begin with an assessment of resources, both potential and involved in production. In addition, an important vector of management policy should be forecasting of short-term and long-term 
results of the enterprise; determination of optimal proportions of resources - potential and those involved in production.

On the other hand, the administrative apparatus is one of the structural components of the resource potential of the enterprise, which shows the interdependence of its components. It should be noted that, in our opinion, the administrative apparatus is one of the key components of the resource potential of the agricultural enterprise, since the economic profitability of the enterprise, the personnel potential, and a business plan with due regard to all benefits and risks strongly depend on competent and timely decisions of the administrative apparatus.

The effectiveness and sustainability of enterprises of the modern domestic agricultural sector depend not only on availability and state of the resource potential, but mainly on its involvement in production and dynamics of its updating. Resource potential is the main recourse basis of any enterprise, and the quality and cost of the manufactured products, as well as the level of development of a particular territory, especially rural, strongly depend on this state. Resourcing of each individual enterprise determines resourcing of the agricultural sector of the state as a whole.

The components of the resource potential of each individual enterprise can be classified based on various grounds. We propose to divide them into objective and subjective components. Objective components include resources which do not depend on human. First of all, it is the climate and environmental conditions of the territory and natural resources. Subjective components of the production process are affected by a person, his personal and professional qualities. The proposed classification shows not only the diversity of the resource potential of agricultural enterprises but also external factors that determine the effectiveness of its implementation. Consider these factors in more detail.

Climate and environmental conditions largely determine both economic specialization of enterprises and regions, and profitability of enterprises. The natural potential should also include land resources, including the quality of land. Russia accounts for 12 percent of the world's arable land and 20 percent of the world's fresh water supply. Of these, 13.6 percent are arable lands of Western Siberia (including those in Omsk region)

The need of society for agricultural products and the need to ensure food security require continuous improvement of agricultural enterprises and response to current challenges

The type of social development is another factor that determines the effectiveness of implementation of the resource potential in the agricultural sector of the economy. Thus, a postindustrial society entails a change in the sectoral proportions of the economy: high-tech production, the service sector, and information technology replace the industrial sectors [16, 17]. The transition to a post-industrial society entailed, on the one hand, a change in the labor market and, on the other hand, a new approach to the selection of specialists. To date, competitive specialists must have knowledge of a foreign language, computer programs, be mobile and able to work in conditions of multitasking and constant change. In this regard, much attention is paid to the system of continuing education as a means of human capital formation in conditions of social change [18].

Social and economic development of a specific territory. The problem of migration, as an example, is especially relevant for the village that is largely due to the poor social infrastructure of rural settlements. The level of social infrastructure guarantees satisfaction of the population needs in almost all areas of life - from working and living conditions to education, medical services, leisure, etc. Deterioration of social infrastructure, that is a reduced number of schools and kindergartens, and culture and sports facilities, poor and irregular medical care, and poor trade services in small settlements are the main problems that impede the development of human capital in rural areas.

We have analyzed the level of development of the social infrastructure institutions of the region through the example of Tara district. Tara municipal district, with a regional center of the city of Tara, is located in the north of Omsk region and is the center of the northern economic region. A total of 45.1 thousand people live in the district, of which $42 \%$ of the population account for rural districts. The economy of Tara region is based on agriculture, forestry and woodworking industry.

The social infrastructure of the region is represented by educational institutions of all levels, healthcare institutions, leisure and service institutions. Analysis of the current situation showed the following. In 2018, 1,995 children attended pre-school educational institutions, including 1,305 children in the city and 690 children in the village, and a steady shortage of places can be observed in the field of preschool education. The number of students in secondary and basic schools and, accordingly, the number of educational institutions are steadily decreasing: in 2016, 28 general education schools were in the district, and only 26 schools were in the district in 2019. Health institutions are represented mainly by feldsher-obstetric centers. The rural population can go to the narrow-profile specialists or undergo a diagnostic examination only in the district or regional center.

The population of rural settlements on the right bank of the Irtysh River is facing particularly acute problems due to poor condition of roads. It is in these settlements, where schools, libraries, and trade objects are closed (over the past year the number of trade objects has decreased by $2.2 \%$ ). Ultimately, this leads to resettlement of villages and their disappearance from the map [19].

State policy is an external factor that affects the development of agricultural enterprises. State interest in certain crops, vectors of agricultural policy, and state priorities in scientific research of agricultural issues - all this affects the resource potential of agricultural enterprises [20].

\section{SUGGESTED MEASURES}

We suggest the following measures that will contribute to effective implementation of the resource potential of agricultural enterprises in the information society. 
1. The strategy of the economic development of the country and the national technological initiative should be the key point for formation of the system of use, dynamics and reproduction of resources.

2. Continuous systematic monitoring of the needs of the state and society, and capabilities of each individual enterprise.

3. The maximum use of political, economic and social forecasting for timely updating and adjustment of the passive and currently used resources.

4. Popularization of the continuing education system as a resource for preparing specialists to meet the challenges of the time.

5. Organization of work focused on provision of social infrastructure facilities, which is especially important for sustainable development of rural areas.

6 . Formation of a positive image of the region in the youth perception and determination of prospects for its development and role in the life of the state.

\section{CONCLUSIONS}

Summarizing modern approaches to the concept of resource potential, we can conclude the following. The concept implies a complex of all tangible and intangible assets, which contribute to the achievement of sustainable economic results. It is important to understand that the resource potential of the region or a single enterprise includes not only currently used resources but also passive assets.

Sustainable development of agricultural enterprises depends on many factors. And resource potential is only one of them. However, competent disposal of the resources available to the enterprise is the key to its successful functioning. The core of the resource potential of any enterprise is its personnel.

\section{References}

[1] E.V. Bogomolova, T.N. Tolstykh, "Identification of the competitiveness potential of entrepreneurial structures as a reserve", Bull. of TSU, vol. 12, pp. 61-65, 2011.

[2] B.I. Smagin, "Methods for assessing the resource potential in agricultural production", Sci. and Technol. Advan. of the Agricult. Sector, vol. 2, pp. 43-49, 2013.
[3] V.A. Svobodin, "Issues of determination and efficiency of the production potential", AIC: Econ. and Manag., vol. 3, pp. 27-30, 1991.

[4] A.P. Shatrova, "Algorithm for implementing the methodology for assessing the resource potential of a service industry enterprise", Probl. of Modern Econ., vol. 3, pp. 393-397, 2011.

[5] A.V. Krasovskaya, A.I. Mansapova, T.M. Veremey, E.V. Yudina, "Special Features of Biology, Technology and Economic Efficiency of Long-Fibred Flax Cultivation in the Subtaiga Zone of Omsk Region, The Fifth Technological Order: Prospects for the Development and Modernization of the Russian Agro-Industrial Sector (TFTS 2019)", Advan. in Soc. Sci., Ed. and Human. Res., vol. 393, 2019.

[6] E.V. Yudina, S.A. Konovalov, "Development Issues and Prospects of Milk Processing Enterprises, The Fifth Technological Order: Prospects for the Development and Modernization of the Russian Agro-Industrial Sector (TFTS 2019)", Advan. in Soc. Sci., Ed. and Human. Res., vol. 393, 2019.

[7] E.V. Sokolova, T.I. Zakharova, "Factors of Formation and Development of Human Capital in Rural Areas, The Fifth Technological Order: Prospects for the Development and Modernization of the Russian AgroIndustrial Sector (TFTS 2019)", Advan. in Soc. Sci., Ed. and Human. Res., vol. 393, 2019.

[8] J.S. Osland, "Journey inward: expatriate hero tales and paradoxes", Human Res. Manag., vol. 39, no. 2-3, pp. 227-239, 2000.

[9] G.M. Spreitzer, M.W. Jr McCall, J.D. Mahoney, "Earley identification of international executive potential", J. of Appl. Psychol., 1997.

[10] R.J. Sternberg, J. Hedlund, "Practical intelligence, g, and work psychology", Human Perform., vol. 15, no. 1-2, pp. 143-160, 2002.

[11] G. Becker, Human capital: A theoretical and empirical analysis with special reference to education. Chicago, 1991.

[12] T.W. Schultz, "Human capital formation by education", J. of Political Econ., vol. 68, 1960.

[13] T. Stewart, "Brainpower", Fortun., June 3, pp. 42-60, 1991.

[14] L. Thurow, Investment in Human Capital. Belmont, 1970.

[15] Transforming our world: the 2030 Agenda for Sustainable Development, Resolution adopted by the General Assembly on 25 September 2015 70/1.

[16] V.A. Chernov, "Implementation of digital technologies in the financial management of economic activity", Reg. Econ., vol. 1, no. 16, pp. 283-297, 2020.

[17] A.G. Svetlakov, I.M. Glotina, "Effect of the information space on the economic security of the region", Reg. Econ., vol. 2, no. 14, pp. 474-484, 2018.

[18] I.A. Korshunov, O.S. Gaponova, N.S. Gaponova, "Adult education and training in the context of regional economic development", Reg. Econ., vol. 1, no. 15, pp. 107-120, 2019.

[19] E.V. Sokolova,, D.V. Kuznetsov, "Main trends in the formation of rural settlements in the territory of Tara (the Irtysh area) between 1920 and 1980" The Turkish Online J. of Design, Art and Communicat. TOJDAC, spec. edit., pp. 2221-2232, 2018. ISSN: 2146-5193

[20] V.P. Neganova, A.V. Dudnik, I"mproving state support for the agricultural sector of the region", Reg. Econ., vol. 2, no. 14, pp. 651-662, 2018. 